\title{
Pengoptimalan Sektor Perekonomian pada UMKM dengan Disusunnya Suatu Laporan Keuangan Sederhana di Dusun Kwarigan, Desa Bakulan, Kecamatan Cepogo, Kabupaten Boyolali
}

\author{
Anasia Fathiyati Mutoharoh a,1, Sigit Muryanto b,2,* \\ ${ }^{a}$ Fakultas Ekonomi, Universitas Boyolali, Boyolali 57315, Indonesia \\ ${ }^{\mathrm{b}}$ Fakultas Pertanian, Universitas Boyolali, Boyolali 57315, Indonesia \\ 1 anasia2406@ gmail.com; ${ }^{2}$ sigit.ms2013@gmail.com \\ * Koresponsendi penulis
}

ARTICLE INFO

Article history

Menerima 26 Agustus 2021

Revisi 30 November 2021

Diterima 30 November 2021

Kata Kunci

UMKM

Financial Statement

Ekonomis

\begin{abstract}
Financial statements have a major influence in assessing, developing marketing strategies and evaluating a business. Kwarigan Hamlet is one of the villages that has several MSME actors, but none of the MSMEs has implemented financial reports properly so that there is no clear evaluation and it is difficult to develop into a larger MSME and it is difficult to determine the business strategy to be run. This article aims to improve the optimization of the economic sector by compiling financial reports for MSMEs in Kwarigan Hamlet and applying them to their business fields and determining the right strategy for the advancement of MSMEs in Kwariganq Hamlet. The results obtained are from the balance sheet financial statements it can be known the amount of assets and laundry business capital for sure. From the Profit and Loss report, it can be used as a benchmark that there is a main production cost, namely clean water which can be kept to a minimum in order to achieve maximum profit because it uses water sourced from wells. From the emphasis on water costs, it can be used for transportation costs for picking up dirty laundry and delivering clean clothes to customers as a marketing solution in order to increase sales turnover. With this strategy, customers will be interested and feel that they are given maximum service from the Laundry business but will still be able to increase profits.
\end{abstract}

This is an open access article under the CC-BY-SA 4.0 license.

\section{Pendahuluan}

Usaha Mikro Kecil dan Menengah (UMKM) merupakan salah bentuk usaha yang memberikan kontribusi terhadap pertumbuhan ekonomi di Indonesia. UMKM merupakan salah satu bentuk solusi masyarakat dalam menghadapi krisis ekonomi seperti pada saat sekarang ini. Kontribusi UMKM terhadap Produk Domestik Bruto (PDB) nasional diproyeksi tumbuh 5\% sepanjang tahun 2019. Menurut Ketua Asosiasi Usaha Mikro Kecil dan Menengah Indonesia (Akumindo), dengan estimasi pertumbuhan itu, total kontribusi UMKM terhadap PDB nasional tahun 2019 dapat mencapai 65\% atau sekitar Rp2.394,5 triliun terutama dari UMKM pemula dengan pemasaran melalui platform daring, diikuti dengan usaha mikro dari sektor jasa kurir. Adapun realisasi kontribusi UMKM terhadap PDB nasional tahun 2018 mencapai sekitar 60,34\%. ( Amrie, 2019). Jumlah pelaku UMKM di Kota Semarang terus mengalami pertumbuhan setiap tahun. Rata-rata pertumbuhan setiap tahun sekitar 1.97\%. Asisten Administrasi Umum Sekda Kota Semarang Agustin Lusin Dwimawati menyampaikan bahwa sampai saat ini total jumlah pelaku UMKM di Kota Semarang 
yang terdaftar sebanyak 11.692 UMKM. Meskipun jumlah yang terdaftar sekitar 11.692 UMKM, namun kenyataan di lapangan jauh lebih dari jumlah yang sudah terdaftar [1].

Dibalik besarnya peran UMKN bagi perekonomian tidak sedikit pula UMKM yang berjalan lambat dan akhirnya harus gulung tikar karena tidak adanya suatu pembukuan keuangan baik dari segi produksi maupun penjualannya. Berbagai masalah pokok yang dihadapi UMKM dengan menggolongkannya menjadi masalah internal dan masalah eksternal. Masalah internal UMKM berfokus pada rendahnya kualitas sumber daya manusia, lemahnya jaringan usaha dan kemampuan penetrasi pasar, kurangnya permodalan, masalah tehnologi, serta masalah organisasi dan manajemen [2]. Usaha Mikro dan Usaha Kecil yang umumnya bergerak dalam industri rumahan belum menyadari pentingnya laporan keuangan, bahkan menganggap tidak memerlukan laporan keuangan karena cukup merepotkan. Kebanyakan transaksi dicatat dalam ingatan, hanya sebagian saja yang berbekas dalam catatan yang "ala kadar" nya pula. Karena semrawutnya pencatatan keuangan tersebut, usaha mikro dan kecil memiliki daya saing yang lemah akibat tidak mengetahui posisi usahanya, apakah mendapatkan untung atau malah merugi [3]. Seharusnya para pelaku UMKM dapat memahami manfaat dari pencatatan akuntansi, hal ini karena aspek penting dari pengelolaan suatu usaha adalah keuangan, maka apabila pengelolaan keuangan pada suatu usaha amburadul atau tidak terkelola dengan baik dapat dipastikan usaha tersebut akan mengalami gejolak dan tidak jarang hingga mengalami gulung tikar [4].

Sepanjang UMKM masih menggunakan uang sebagai alat transaksinya, akuntansi sangat dibutuhkan oleh UMKM [5]. Laporan Keuangan digunakan sebagai dokumen pengajuan persyaratan kredit. Permasalahan riil yang dihadapi para pelaku UMKM diantaranya adalah kurangnya pengetahuan mengenai persyaratan pengajuan kredit atau pembiayaan ke Bank, minimnya pemahaman mengenai laporan keuangan, kurangnya kemampuan untuk membuat laporan keuangan dan tidak banyak tersedia pelatihan terkait permasalahan tersebut. Demikian pentingnya pelaku usaha UMKM, pemerintah telah memberikan perhatian khusus menciptakan standar akuntansi keuangan entitas mikro kecil menengah (SAK EMKM) sebagai pedoman bagi pelaku usaha UMKM untuk membuat laporan keuangan sederhana yang memiliki akses pendanaan yang semakin luas ke sektor perbankan agar terwujud UMKM yang maju, mandiri, dan modern. Dibandingkan dengan pilar SAK lainnya yang ada di Indonesia, standar ini sengaja dibuat lebih sederhana dibandingkan dengan SAK umum berbasis IFRS dan SAK ETAP. Adapun cara penyajian laporan keuangan EMKM telah disusun secara rinci pada SAK EMKM yang dimana penyajiannya harus konsisten, informasi keuangan yang komparatif, serta lengkap [6].

Penyusunan laporan keuangan berdasarkan pada standart akuntansi keuangan merupakan suatu bentuk peningkatan kualitas laporan keuangan yang akan memberikan dampak dalam peningkatan kredibilitas laporan keuangan. Penerapan SAK EMKM selama dua tahun berturut-turut dalam laporan keuangan entitas disusun dengan menggunakan asumsi dasar akrual dan kelangsungan usaha. sebagaimana juga digunakan entitas selain entitas mikro kecil dan menengah serta menggunakan konsep entitas bisnis. Semua pihak sangat akan mengerti pentingnya laporan keuangan dalam usaha [7]. Akuntansi konsep kesatuan ekonomi (economic entity concept) merupakan konsep yang sangat ideal untuk Usaha Mikro Kecil Menengah (UMKM). Karena dengan menggunakan konsep entitas UMKM akan mengetahui laba operasional usaha yang sebenarnya, disebabkan dana yang didapat murni hasil operasional usahanya tanpa tercampur dengan harta milik pribadi maupun orang lain tanpa merasa kebingungan lagi apakah harta milik pribadi ataupun milik perusahaan [8]. Keberadaan dan keberlangsungan UMKM tidak terlepas dari bagaimana UMKM tersebut mengelola usahanya. Untuk dapat menjalankan usahanya secara terus menerus, UMKM juga harus melakukan pengelolaan keuangan dengan baik dan benar. Adanya pemisahan pengelolaan keuangan dari pemiliknya dapat mendorong UMKM menjadi lebih mandiri. Perwujudan pengelolaan keuangan yang baik tentunya perlu didukung dengan penyusunan laporan keuangan sesuai dengan standar akuntansi keuangan yang digunakan oleh UMKM [9].

Usaha Mikro Kecil dan Menengah (UMKM) Sesuai dengan definisi Undang-Undang No. 9 Tahun 1995 Usaha Kecil merupakan usaha produktif dengan skala kecil. Usaha kecil memiliki kriteria kekayaan bersih paling tinggi Rp 200.000.000,00 (dua ratus juta rupiah), kekayaan Usaha Kecil ini tidak termasuk tanah dan bangunan tempat usaha. Usaha kecil memiliki hasil penjualan paling banyak Rp 1.000.000.000,00 (satu milyar rupiah) per tahun dan memiliki untuk memperoleh 
kredit dari bank maksimal di atas Rp 50.000.000,00 (lima puluh juta rupiah). Berdasarkan UndangUndang Republik Indonesia No.9 Tahun 1995 tentang Usaha Kecil dinyatakan dalam pasal 1 bahwa "Usaha kecil adalah kegiatan ekonomi rakyat yang berskala kecil dan memenuhi kriteria kekayaan bersih atau hasil penjualan tahunan serta kepemilikan sebagaimana diatur dalam Undang - undang ini" [10].

Kementrian Koperasi dan UMKM mendefinisikan UMKM sebagai Usaha Mikro adalah usaha produktif milik orang perorangan dan/atau badan usaha perorangan. Memiliki kekayaan bersih paling banyak Rp. 50 juta tidak termasuk tanah dan bangunan dan memiliki hasil penjualan tahunan paling banyak Rp. 300 juta. Usaha Kecil adalah usaha ekonomi produktif yang berdiri sendiri, yang dilakukan oleh orang perorangan atau badan usaha yang bukan merupakan anak perusahaan atau bukan cabang perusahaan yang dimiliki, dikuasai, atau menjadi bagian baik langsung maupun tidak langsung dari usaha menengah atau usaha besar. Memiliki kekayaan bersih lebih dari Rp. 50 juta sampai dengan paling banyak Rp. 500 juta tidak termasuk tanah dan bangunan atau memiliki hasil penjualan tahunan lebih dari Rp. 300 juta sampai dengan paling banyak Rp. 2,5 miliar. Usaha Menengah adalah usaha ekonomi produktif yang berdiri sendiri, yang dilakukan oleh orang perseorangan atau badan usaha yang bukan merupakan anak perusahaan atau cabang perusahaan yang dimiliki, dikuasai, atau menjadi bagian baik langsung maupun tidak langsung dengan usaha kecil atau usaha besar dengan jumlah kekayaan bersih atau hasil penjualan tahunan. Memiliki kekayaan bersih lebih dari Rp. 500 juta sampai dengan paling banyak Rp. 10 miliar tidak termasuk tanah dan bangunan atau memiliki hasil penjualan tahunan lebih dari Rp. 2,5 miliar sampai dengan paling banyak Rp. 50 miliar [11].

Akses Pembiayaan Usaha Mikro Kurangnya akses pembiayaan merupakan hambatan utama bagi pertumbuhan dan pengembangan usaha mikro karena lembaga keuangan formal atau komersial ragu untuk mengucurkan pinjaman kepada mereka. Lembaga keuangan formal menganggap jaminan yang diberikan oleh pengusaha mikro tidak layak. Hal ini dikarenakan keadaan produksi sering kali beresiko dan tidak stabil sehingga dapat berakibat pada kegagalan pelunasan kredit. Lembaga keuangan formal atau komersial lebih cenderung menyalurkan kredit kepada perusahaan yang berskala besar dan beresiko rendah [12].

Pembukuan dan Akuntansi Proses akuntansi memasukkan fungsi-fungsi pembukuan didalamnya. Pembukuan biasanya hanya melibatkan pencatatan peristiwa-peristiwa ekonomi, maka pembukuan merupakan satu bagian proses akuntansi. Sedangkan akuntansi melibatkan keseluruhan proses pengidentifikasian, pencatatan, dan pengomunikasian peristiwa-peristiwa ekonomi [10].

Definisi Laporan keuangan ialah catatan informasi keuangan suatau perusahaan pada periode akuntansi yang menggambarkan kinerja perusahaan tersebut. Laporan keuangan berguna bagi bankir, kreditor, pemilik, dan pihak-pihak yang berkepentingan dalam menganalisis serta menginterpretasikan kinerja keuangan dan kondisi perusahaan [14]. Laporan keuangan akan menjadi salah satu bahan penilaian yang penting, karena entitas ini bekerja berdasarkan sebuah anggaran dan realisasi anggaran tersebut tercantum dalam laporan keuangan, baik untuk pemerintah ataupun pelaku usaha. Laporan keuangan merupakan salah satu media yang dapat digunakan untuk mengukur kinerja sebuah entitas atau usaha yang dijalankan [13]. Suhairi, 2004 dalam Ketut menyatakan bahwa semakin kompleks suatu kegiatan operasional perusahaan maka penyusunan laporan keuangan semakin penting untuk diterapkan. Hasil dari penyusunan laporan keuangan semakin tersebut adalah berupa informasi yang dapat digunakan untuk menunjukkan kondisi keuangan perusahaan [14].

Sistem informasi akuntansi adalah "Susunan berbagai fomulir, catatan, peralatan, termasuk komputer dan perlengkapannya serta alat komunikasi, tenaga pelaksananya, dan laporan yang terkoordinasikan secara erat yang didesain untuk mentransformasikan data keuangan menjadi informasi yang dibutuhkan manajemen" [10]. Kinerja pada organisasi atau usaha, dapat dikelompokkan atas kinerja strategic, kinerja administrastif dan kinerja operasional. Kinerja strategik biasanya berkaitan dengan strategi dalam penyesuaian kebijakan strategik di pegang oleh topmanajer karena menyangkut strategi menghadapi pihak luar, dan juga kinerja strategik harus mampu membuat visi ke depan tentang kondisi makro ekonomi negara yang berpengaruh pada kelangsungan organisasi; Kinerja administratif berkaitan dengan kinerja administrasi organisasi, termasuk didalamnya tentang struktur administratif yang mengatur hubungan otoritas (wewenang) 
dan tanggung jawab dari orang yang menduduki jabatan atau bekerja pada unit-unit kerja yang terdapat dalam organisasi. Disamping itu, kinerja administratif berkaitan dengan kinerja dari mekanisme aliran informasi antar unit kerja dalam organisai, agar tercapai sinkronisasi kerja antar unit kerja; Kinerja operasional berkaitan dengan efektifitas penggunaan setiap sumber daya yang digunakan organisasi. Kemampuan mencapai efektifitas penggunaan sumberdaya (modal, bahan baku, teknologi dan lain-lain) tergantung kepada sumberdaya manusia yang mengerjakan [15].

Tujuan dari penelitian ini adalah untuk mengetahui sejauh mana penerapan atas pencatatan keuangan yang dilakukan oleh UMKM laundry di Dusun Kwarigan. Adapun Manfaat Penelitian ada dua yaitu manfaat teoritis yakni diharapkan mampu memperluas pengetahuan tentang bagaimana penerapan pencatatan keuangan pada UMKM dan pentingnya pencatatan keuangan terhadap usaha yang dijalankan dan Manfaat praktis yakni diharapkan mampu memberikan manfaat praktis bagi pelaku usaha kecil, sehingga dapat memahami bahwa pencatatan keuangan merupakan hal yang tidak dapat diabaikan dalam mengelola sebuah usaha dan diharapkan pelaku usaha dapat menerapkan pencatatan keuangan pada pengelolaan usaha sehingga berdampak pada kinerja usaha.

Di Dusun Kwarigan, Desa Bakulan, Kecamatan Cepogo, Kabupaten Boyolali terdapat Beberapa UMKM seperti usaha produksi roti, Laundry, dan makanan tradisional. Dari berbagai usaha ini selain bertujuan untuk mencukupi kebutuhan para pelaku usaha tentunya diharapkan dapat bermanfaat bagi tingkat perekonomian masyarakat Dusun Kwarigan, tetapi belum ada pelaku UMKM yang menjalankan usaha nya dengan disertai Pembukuan keuangan sehingga usahanya dapat dikatakan belum optimal. Apalagi di era pandemi covid-19 yang mengakibatkan omzet penjualan pada beberapa UMKM di Dukuh Kwarigan ini mengalami penurunan yang cukup signifikan. Berdasarkan identifikasi permasalahan diatas, dilaksanakan tim KKN Universitas Boyolali melakukan kegiatan penyuluhan mengenai pentingnya suatu laporan keuangan bagi suatu usaha dan pendampingan pembuatan laporan keuangan sederhana bagi UMKM dibidang usaha laundry di Dusun Kwarigan untuk membantu mengevaluasi penyebab belum optimalnya usaha tersebut dan menemukan strategi yang tepat bagi perkembangan usaha kedepannya.

\section{Metode}

Program yang dilaksanakan untuk mencapai hasil dari tema KKN yang pertama adalah melakukan penyuluhan mengenai pentingnya suatu laporan keuangan bagi UMKM dan manfaatnya bagi perkembangan usaha kedepannya. Kedua menganalisis strategi yang tepat bagi perkembangan usaha UMKM yang berpedoman dari laporan keuangan yang telah dibuat. Kemudian Bersamasama dengan pelaku usaha melakukan identifikasi aset, biaya produksi, harga jual produk dan penyusunan pembuatan laporan keuangan sederhana bagi UMKM.

\section{Hasil dan Pembahasan}

Berdasarkan identifikasi masalah pada beberapa UMKM di Dusun Kwarigan, Penyusun tertarik untuk melakukan penyuluhan mengenai pentingnya suatu laporan keuangan serta manfaatnya bagi suatu usaha seperti untuk menilai kondisi usaha, sebagai bahan evaluasi dan pertanggungjawaban, serta menentukan langkah yang akan diambil para pelaku usaha kedepan agar dapat berkembang dengan baik. Secara umum laporan keuangan adalah berkas yang berisi pencatatan uang. Maksudnya adalah laporan yang berisi segala macam transaksi yang melibatkan uang, baik transaksi pembelian maupun penjualan dan kredit. Biasanya laporan ini dibuat dalam periode tertentu. Penentuannya ditentukan oleh kebijakan perusahaan apakah dibuat setiap bulan atau setiap satu tahun sekali Seperti pada Fig. 1. 


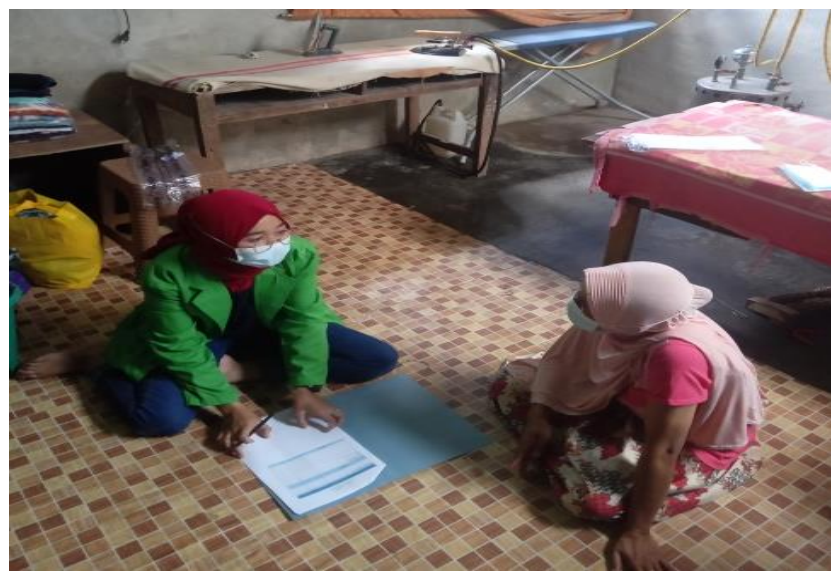

Fig. 1. Penyuluhan pentingnya penyusunan Laporan Keuangan

Berbekal ilmu yang telah didapat di perkuliahan dan materi mengenai penyusunan laporan keuangan penyusun melakukan penyuluhan kepada para pelaku UMKM lalu bersama sama menyusun laporan keuangan sederhana diantaranya laporan neraca dan laporan Laba Rugi. laporan neraca adalah gabungan dari segala laporan keuangan. Ini juga dibuat dalam waktu tertentu yang normalnya adalah satu tahun sekali. Sedangkan Laporan laba rugi adalah berkas yang di dalamnya berisi data-data pemasukan dan pengeluaran perusahaan. Jika lebih banyak pemasukan dibandingkan pengeluaran maka disebut laba perusahaan. Sebaliknya jika yang lebih besar adalah pengeluaran, tentu perusahaan merugi. Tujuannya adalah untuk menentukan langkah terkait finansial di tahun selanjutnya. Tujuan dibuatnya laporan laba rugi adalah untuk mengetahui apakah perusahaan mendapatkan keuntungan atau justru kerugian. Efeknya ialah mempertahankan yang untung dan sebisa mungkin mencari solusi bagaimana yang rugi bisa tertutupi.
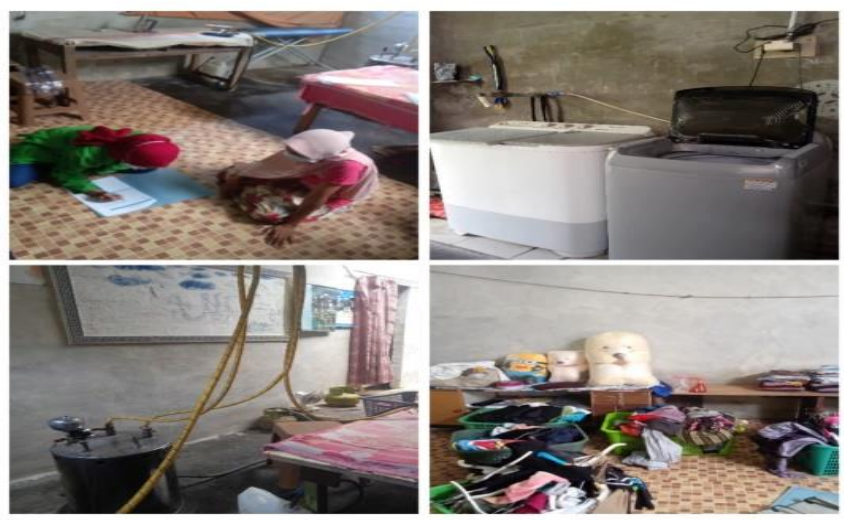

Fig. 2. Pendataan aset tetap usaha laundry Ibu Umi.

Fig. 2 merupakan kegiatan di hari minggu tanggal 7 Maret 2021, penyusun mengunjungi rumah Ibu Umi di Dusun Kwarigan dengan bidang usaha laundry .penyuluhan ini lebih ditekankan pada pemisahan antara kas usaha Laundry dengan kas pribadi Ibu Umi sehingga memdahkan untul pembuatan Laporan Arus kas usaha laundry tersebut. Setelah melakukan penyuluhan dan identifikasi usaha Ibu Umi penyusun bersama Ibu Umi melakukan pembuatan laporan keuangan sederhana mengenai Lapora Neraca dan Laporan Laba Rugi seperti yang terlihat di Fig. 3. 


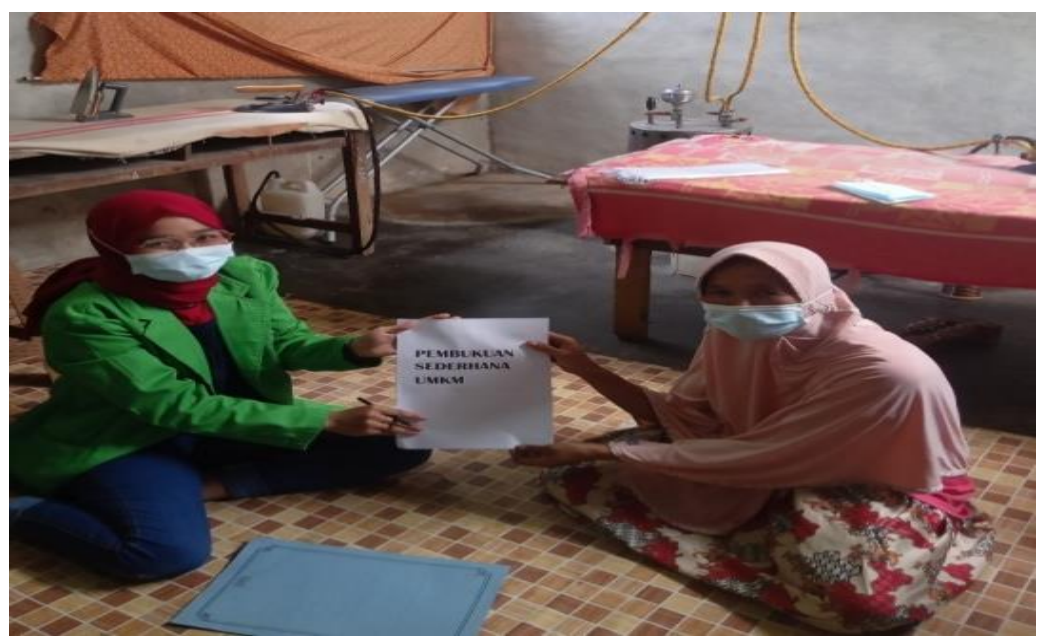

Fig. 3. Hasil Pembuatan Laporan Keuangan Usaha Laundry

Dari laporan keuangan neraca dapat diketahui besarnya aset serta besarnya modal usaha laundry Ibu Umi secara pasti. Sedangkan dari hasil laporan laba rugi dapat diketahui mengenai besarnya laba bersih Ibu Umi. Dari laporan Laba Rugi ini dapat dijadikan patokan bahwa terdapat biaya produksi utama yaitu air bersih yang dapat ditekan seminimal mungkin agar mencapai laba yang maksimal karena Ibu Umi menggunakan air yang bersumber dari sumur. Dari penekanan biaya air ini dapat dipergunakan untuk biaya transportasi penjemputan cucian kotor dan pengantaran pakaian bersih kepada para pelanggan sebagai solusi pemasaran dalam rangka peningkatan omzet penjualan Ibu Umi. Dengan strategi ini para pelanggan akan tertarik dan merasa diberikan service yang maksimal dari usaha Laundry Ibu Umi namun Ibu Umi akan tetap dapat menaikan Laba karena biaya transportasi tidak sebesar biaya air yang seharusnya dikeluarkan jika sumber air berasal dari pembelian pihak lain. Fig. 4 penulis menyerahkan banner sebagai dukungan untuk promosi UMKM Yaya Laundry yang bisa dipasang di depan toko ini.

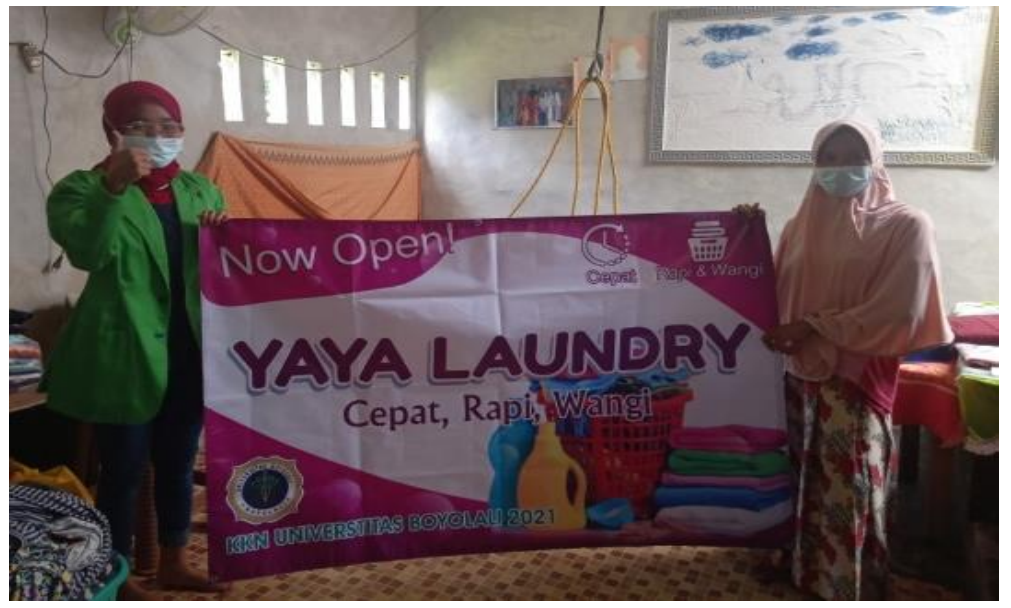

Fig. 4. Penyerahan Banner untuk promosi Ibu Umi

\section{Kesimpulan}

Pelaksanaan kegiatan KKN Universitas Boyolali tahun 2021 di Dusun Kwarigan, Desa Bakulan, Kecamatan Cepogo, Kabupaten Boyolali secara umum dinilai dapat berjalan dengan lancar. Tujuan dan target khusus yaitu untuk membuka pandangan pelaku UMKM mengenai pentingnya penyusunan Laporan Keuangan serta manfaatnya bagi suatu perkembangan usaha selanjutnya serta menerapkannya pada bidang usaha yang dimiliki. 


\section{Daftar Pustaka}

[1] R. Widhiastuti, N. Farliana, and J. Pendidikan Ekonomi Universitas Negeri Semarang ABSTRAK, "MODEL AKUNTANSI SEDERHANA BAGI UMKM MAKANAN KOTA SEMARANG SIMPLE ACCOUNTING MODEL FOR FOOD UMKM, SEMARANG CITY," [Online]. Available: http://infowisata.ukm.semarangkota.go.id/infouk.

[2] E. Purwanti, "ANALISIS PENGETAHUAN LAPORAN KEUANGAN PADA UMKM INDUSTRI KONVEKSI DI SALATIGA,” Among Makarti, vol. Vol.10, 2017.

[3] W. O. Rayyani, M. N. Abdi, E. Winarsi, and Warda, "PENINGKATAN DAYA SAING UMKM MELALUI OPTIMALISASI PENYUSUNAN LAPORAN KEUANGAN," $J$. Dedik. Masy., pp. 97 - 105, 2020.

[4] P. Akuntansi, R. Vega Savitri, and K. Kunci, "PENCATATAN AKUNTANSI PADA USAHA MIKRO KECIL DAN MENENGAH (STUDI PADA UMKM MR. PELANGI SEMARANG)," vol. 5, no. 2, pp. 117-125, 2018, [Online]. Available: www.depkop.go.id.

[5] J. Junaidi, "Pelatihan Manajemen Keuangan sebagai Upaya Peningkatan Daya Saing UMKM dalam Menghadapi MEA di Kecamatan Tomoni Kabupaten Luwu Timur," Reson. J. Ilm. Pengabdi. Masy., vol. 1, no. 1, pp. 46-51, 2017, doi: 10.35906/jipm01.v1i1.238.

[6] Y. Agustina, S. Setianingsih, and Y. D. Santoso, "Pelatihan Penyusunan Laporan Keuangan Bagi Entitas Mikro, Kecil, dan Menengah Bidang Usaha Dagang pada UMKM Binaan Pusat Inkubasi Bisnis Syariah Majelis Ulama Indonesia," Interv. KOMUNITAS J. Pengabdi. Masy., vol. Vol. 1, No, 2019.

[7] D. Amatullah Azizah Rachmanti and M. Hariyadi, "ANALISIS PENYUSUNAN LAPORAN KEUANGAN UMKM BATIK JUMPUT DAHLIA BERDASARKAN SAKEMKM," 2019.

[8] G. D. Larasdiputra, N. Ketut, and E. Suwitari, "PENGELOLAAN KEUANGAN USAHA MIKRO KECIL MENENGAH (UMKM) BERBASIS ECONOMIC ENTITY CONCEPT," 2020.

[9] A. Firmansyah, A. Arham, and A. M. Elvin Nor, "Edukasi Akuntansi dan Bimbingan Teknis Penyusunan Laporan Keuangan Usaha Mikro, Kecil, dan Menengah," Wikrama Parahita J. Pengabdi. Masy., vol. 3, no. 2, pp. 57-63, Nov. 2019, doi: 10.30656/jpmwp.v3i2.1766.

[10] P. Rosita Andarsari Dosen STIE Asia Malang Justita Dura Dosen STIE Asia Malang, "IMPLEMENTASI PENCATATAN KEUANGAN PADA USAHA KECIL DAN MENENGAH (Studi pada Sentra Industri Kripik Tempe Sanan di Kota Malang)."

[11] A. Akuntansi Yang Diterapkan UMKM, D. Syaiful Akbar, N. Darna, and B. Prawiranegara, "Halaman 243 ANALISIS AKUNTANSI YANG DITERAPKAN UMKM."

[12] D. Putri Hapsari and A. Nahdiatul Hasanah, "MODEL PEMBUKUAN SEDERHANA BAGI USAHA MIKRO DI KECAMATAN KRAMATWATU KABUPATEN SERANG," J. Akunt., vol. 4, no. 2, 2017.

[13] N. J. Almahdali and S. K. Djawa, "PENDAMPINGAN PENYUSUNAN LAPORAN KEUANGAN PADA KELOMPOK DASA WISMA."

[14] K. A. Warsadi, N. T. Herawati, and I. P. Julianto, "PENERAPAN PENYUSUNAN LAPORAN KEUANGAN PADA USAHA KECIL MENENGAH BERBASIS STANDAR AKUNTANSI KEUANGAN ENTITAS MIKRO, KECIL, DAN MENENGAH PADA PT. MAMA JAYA,” e-Journal S1 Ak Univ. Pendidik. Ganesha, vol. Volume: 8, 2017. 
[15] S. Nurlaela, "KEMAMPUAN MENYUSUN LAPORAN KEUANGAN USAHA KECIL MENENGAH PENGARUHNYA TERHADAP KINERJA UKM KERAJINAN GITAR DI KABUPTEN SUKOHARJO,” J. Paradig., vol. Vol. 12, N, 2015. 